NBER WORKING PAPER SERIES

NATIONAL PRICE LEVELS AND THE PRICES

OF TRADABLES AND NONTRADABLES

Irving B. Kravis

Robert E. Lipsey

Working Paper No. 2536

NATIONAL BUREAU OF ECONOMIC RESEARCH 1050 Massachusetts Avenue

Cambridge, MA 02138

March 1988 
NBER Working Paper \#2536

March 1988

National Price Levels and the Prices of Tradables and Nontradables

\section{. ABSTRACT}

This paper examines changes in national price levels and prices of tradables and nontradables and relates them to changes in variables found earlier to be associated with price level differences among countries.

Across countries, national price levels increase systematically with the level of a country's per capita income, and the ratios of tradables to nontradables prices decrease. Over time, increases in per capita income are generally associated with increases in price levels in the industrial countries, although the opposite relationship tended to prevail among developing countries. Increases in income are associated with declines in the ratio of tradables to nontradables price levels more consistently than with the increases in general price leveis. Increases in the exchange value of a currency are also associated with declines in the price leveis for tradables relative to nontradables. Countries with price levels that were high or low relative to those predicted by the structural equations tended to move toward those predicted levels.

Irving B. Kravis

University of Pennsyivania

Department of Economics

Philadeiphia, PA 19104

(215) $898-5692$ and

National Bureau of Economic Research

269 Mercer Street

New York, NY 10003
Robert E. Lipsey

Queens College and

Graduate Center, CUNY

Fiushing, NY 11367

(718) 520-7064

and

National Bureau of Economic Research

269 Mercer Street

New York, NY 10003

(212) 995-3447 
NATIONAL PRICE LEVELS AND THE PRICES OF TRADABLES AND NONTRADABLES

Irving B. Kravis

Robert E. Lipsey

The recent debates about the appropriateness of the current U.S. exchange rate and the effects of the decline in the exchange value of the dollar since early 1985 have focussed attention on the national price level as an object of economic policy. There seems to be little doubt in the minds of most participants in the debates that the U.S. price level, expressed in any of the world's major currencies, rose greatly from 1980 through early 1985 and since then has fallen sharply. In other words, the purchasing power of a dollar over U.S. goods first declined and then increased relative to the purchasing power of the amount of British, German, and Japanese goods that could be purchased in their own countries with the E. DM and Yen that a dollar exchanged for in currency markets. The Japanese price level, for example, is thus defined as the purchasing power of the Yen (the number of Yen required to buy in Japan the same goods and services a dollar buys in the U.S.) divided by the exchange rate (the number of Yen required to buy a dollar on the foreign exchange market).

The concepts of purchasing power parity and the "law of one price" are so convenient and so firmly embedded in trade theory and exchange rate theory that it requires some effort to put them aside to discuss national price levels, but the widely fluctuating exchange rates of the 1970 s and 1980s have compelled attention to these issues. Most of that attention

*University of Pennsylvania, Philadelphia, PA, 19104 and NBER: Queens College and Graduate Center, CUNY, and NBER, 269 Mercer Street, New York, N.Y., 10003. The statistical work for this paper was done by David Robinson and Linda Molinari. 
has been focussed on "real exchange rates" (usually defined as the reciprocal of what we refer to as changes in national price levels), the relation of exchange rate changes to domestic price changes, but there has been some research centered on explaining the structure of price levels at particular times (Bhagwati, 1984; Clague, 1985 and 1986; Kravis and Lipsey, 1983 and 1987). One reason for studying the structural, or cross-sectional determinants of price levels is that an understanding of the levels from which changes begin is important for explaining the changes.

In this paper we concentrate on the price levels for tradables and nontradables, describing what has happened both in cross sections and over time, and analyze the effects on price levels of changes in income, which we found in our previous work to have been by far the major influence in cross-section analyses of price levels. The role of changes in exchange rates is also briefly described.

\section{The Model}

The approach taken here is based on a highly simplified formulation of the factors that determine differences in national price levels acros: countries and applies it to the comparison among countries of changes over time. In a general equilibrium setting the price level is a variable influenced by several long-term or permanent characteristics of an economy. Also it both influences and is influenced by the variuos components of monetary and fiscal policy and of international economic policy (choice of exchange rate regimes and of exchange rate levels, degree of control over capital movements, extent of autarkic policies). 
Across countries, price levels are expected to be positively associated with income because prices of nontradables are higher relative to prices of tradables in rich countries than in poor countries. That might be because productivity differences between rich and poor countries are smaller for nontradables (mainly services) than for tradables, or because nontradables are more labor-intensive than tradables and labor is relatively cheap in poor countries (Kravis and Lipsey, 1983; Bhagwati, 1984). The relative price of nontradables would completely determine the price level if prices of tradables in all countries were forced into equality by competition and if the shares of tradables and nontradables in output were identical in all countries. While neither of these conditions holds at all completely, it is true that prices of tradables, though higher in rich countries because they almost always are sold with an admixture of services, are much more simi'a- siong countries than prices of nontradables. Thus the ra:io of tradables prices to nontradables prices (PTR/PNT) is lower, the higher a country's per capita income. Shares of nontradables in output, the weights of nontradables in total GDP price ievels, are either uncorrelated with income levels, and therefore do not affect the income-price level relationship, or are positively correlated with per capita income and therefore reinforce the income-price level relationship (Kravis and Lipsey, 1983, p. 15).

What implications does the inter-country relationship between income and the PTR/PNT ratio have for changes in that ratio over time? The intercountry relationship could conceivably reflect either the effects of relative income levels (e.g. 90 per cent of the U.S. level vs. 45 per cent) or 
the effects of absolute income levels $(\$ 20,000$ in international prices vs. $\$ 10,000)$. If we assume that the relationship observed is with the absolute level of income, we would expect that over time, with rising incomes, the ratios should fall.

What implications, if any, does the inter-country relationship between income and $\mathrm{PL}$ have for changes in $\mathrm{PL}$ over time? since $\mathrm{PL}$ is defined in relative terms (for example, with U.S. = 100), it is the relative income changes that are pertinent. If a country's per capita income rises relative to the U.S. its relative price level should also rise.

There could also be short-run determinants of PLs and of PTR/PNTs not operating through the structural, or long-run relationships we have described. A rise in the exchange value of a country's currency, not offset by changes in domestic currency prices will, by definition, produce an increase in PL. The assumptions outlined above imply that it should also produce a fall in the PTR/PNT ratio because prices of tradables are more constrained by international competition than prices of nontradables.

Although real income per capita is the predominant factor influencing the price level, other factors may play some role. In our earlier work we suggested that the degree of openness to trade may also influence price levels and changes in them because a high propensity to trade $[(X+M) / G D P]$ pulls a country's prices towards the world average -- upward for poor countries and downwards for rich countries. And we expected a high share of tradables in output to reduce a country's price level. 1 
II. What do the cross section data tell us about the relation of price

levels to per capita income?

The cross-section relations between price levels and income (i.e., real GDP per capita) may be summarized as follows:

1. Price levels tend, as expected, to be lower in poor countries than in rich ones. And also as expected, the differences are greater for nontradables than for tradables. ${ }^{2}$ These relationships may be $i l l u s t r a t e d$ by the data in Table 1 . The simple $\vec{r}^{2}$ between the GDP price level $(P L)$ and real GDP per capita (y) is .52 for the 60 countries.

2. The price level for tradables (PTR) rises as income rises, despite the near unanimity found in the literature on real exchange rates that the law of one price prevails for tradables.

3. The relationship between nontradable prices (PNT) and real GDP per capita is stronger than for tradables; the $\vec{r}^{2}$ is .66 for nontradables against .31 for tradables. Also, nontradables are much less costly in poor and rise more sharply in the progression of countries up the income scale.

4. These relationships produce a negative correlation between the ratio of tradables to nontradables prices and real GDP per capita. This relationship applies even to subsets of countries for which the association between PL and PTR on the one hand and real GOP per capita on the other hand is weak or insignificant, notably Africa.

Thus, the cross section data conform in the main to the model set out above.

Going beyond these simple relationships in which real GDP per capita is 
the only independent variable, we have recomputed the structural price level equations for PL, PTR, and PNT calculated in previous work for 3-year averages beginning with 1960-62. The calculations performed for this paper are based on the 1980 benchmark data (ICP Phase IV, reported upon in United Nations and Commission of the European Communities, 1986) rather than the 1975 survey used previously (ICP Phase III, reported on in Kravis, Heston, and Summers, 1982\}.

The recalculated equations generally confirm the results in Kravis and Lipsey (1987), as can be seen in Appendix Tables 1, 2, and 3 . Again, the nontradable prices are better explained than tradables. In the entire set of equations, both the openness of the economy and the share of tradables in output, when the coefficients were statistically significant, played the expected role in structural equations using them. However, their effect was not at all as large or as consistent as that for income, especially in the later periods. In the study based on the earlier data, we found that while deviations from individual price levels from equality showed little sign of evaporating even after 20 years, the deviations from the levels predicted by our structural equations did tend to diminish substantially. The lower degree of persistence of these deviations suggest that the structural equations come at least a little closer to defining long run equilibria than the assumption of identical price levels in all countries. With the data used here, we confirm these results for the floating exchange rate period, even using a single equation for all the three-year periods from 1972 through 1984 (Appendix Tables 4,5 , and 6 ). 
III. The intertemporal behavior of national price levels

If the intertemporal behavior of national price levels could be inferred from the cross section findings, countries with faster growth in per capita GDP should have larger price level increases and more rapidly declining ratios of tradables price levels to nontradables price levels.

For the period as a whole, price levels rose more in the industrial countries than in the developing countries (an average of $1.74 \%$ per annum in 11 developed countries vs. $0.48 \%$ in 33 LDC's). Rates of internal inflation were higher on average in the LDCs but currency depreciation kept the rise in PL, PTR and PNT in check. For PL, for example, a $5.18 \%$ growth rate in internal (own currency) prices relative to the U.S. was offset by a 4.68\% depreciation, leaving the growth of $\mathrm{PL}$ at $0.48 \%$ per annum $(1.0518 \div$ $1.0468=1.0048)$. The prices of tradables rose less than the prices of nontradables in developed countries, while the opposite was the case in the LDCs. Thus the PTR/PNT ratio of the industrial countries declined relative to that of the LDCs; this was true in both exchange rate subperiods (fixed and floating) and in the period as a whole.

These changes do not necessarily point to the influence of income per capita, even in developed countries where the PTR/PNT moved in the expected direction. The same result could have been produced by a more rapid growth of productivity in tradables (goods) production than in nontradables (chiefly services) production.

A direct test of association with income growth can be made by relating trend rates of change in $\mathrm{PL}$ to trend rates of change in per capita income across countries. The results are shown in Table 2 . 
The expected positive relationship is present for the industrial countries, but for the developing countries the relationship is negative.

The expectation regarding the relationship between tradables and nontradables prices fares better. Whatever the direction of the relationship between trends in per capita income and trends in price levels, the coefficient for income is algebraically larger in the equations for tradables. This is also true for the subperiods (before 1971 and afterwards) except in one of the six comparisons that could be made.

The results above for developing countries suggest that changes in exchange rates affect the ratio of tradables to nontradables price levels. We tested that relationship for the floating exchange rate era by relating changes from one three year period to another in the tradables/nontradables price ratios to changes in exchange rates. (Three year averages were used to iron out some of the sharper fluctuations in exchange rates). As predicted, the relationship was consistently negative: a rise in the exchange value of a country's currency reduced the PTR/PLN ratio (Appendix Table 7). The coefficient for the exchange rate change was statistically significant in three out of four periods. Changes in real income per capita did not have any statistically significant effect on the ratio.

The poor predictions of price level change from changes in income alone bring us back to the reason for our interest in the cross-section relationship. That is the expectation that the change in price level in one period will reflect not only the events of that period but how the actual price level compared with that implied by the structural, long-term determinants of price levels at the beginning of the period. That is, if a 
country's price level was "high" at the beginning of a period, considering its income per capita and other long-term determinants of price levels, we would expect it to fall in subsequent periods, given whatever changes take place in structural variables. We could not find evidence for this over short periods, but it was typically true over periods of ten or twenty years (Appendix Table 8 ). The coefficients of the initial residual in the price equation were always negative and usually statistically significant.

Thus, taking fairly long term movements in price levels, comparing them from one three-year period to another and using our structural equations to define deviations from equilibrium, we find that deviations from the "equilibrium" defined by our structural equations have the expected negative relations to subsequent price level movements. The structural equations thus give some meaning beyond purchasing power parity to the idea that a country's price level, and by implication, its exchange rate, can be "too high" or "too low".

\section{Conclusion}

Across countries, national price levels increase systematically with the level of a country's per capita income, and the ratios of tradables to nontradables prices decrease. These cross-section relationships carry over to some extent to changes over time. Increases in per capita income are generally associated with increases in price levels in the industrial countries, although the opposite relationship tended to prevail among developing countries. Large increases in income are associated with large declines in the ratio of tradables to nontradables price levels more consistentiy than 
with the increases in general price levels. Large increases in the exchange value of the currency are also associated with declines in the price levels for tradables relative to nontradables. Countries with price levels that were high or low relative to those predicted by the structural equations tended to move toward those predicted levels. 


\section{References}

1. Bhagwati, Jagdish, "Why Are Services Cheaper in Poor Countries?", Economic Journal, June 1984, 94, 279-286.

2. Clague, Christopher, "A Model of Real National Price Levels", Southern Economic Journal, April 1985, 51, 998-1017.

3. , "Determinants of the National Price Level: Some

Empirical Results", Review of Economics and Statistics, Volume LXVIII, No. 2, May $1986,320-323$.

4. Kravis, Irving B., Alan Heston, and Robert Summers, World Product and Income, Baltimore, Johns Hopkins Press for the World Bank, 1982.

5. Kravis, Irving B., and Robert E. Lipsey, Toward an Explanation of National Price Levels, Princeton Studies in International Finance, No. 52, Princeton University, International Finance Section, 1983.

6. and , "The Assessment of National Price Levels", in

Sven W. Arndt and J. David Richardson, Real-Financial Linkages Among Open Economies, Cambridge, Massachusetts, MIT Press, 1987.

7. United Nations and Commission of the European Communities, World Comparisons of Purchasing Power and Real Product for 1980, Phase IV of the International Comparison Project (ICP), United Nations and Eurostat, 1986. 


\section{Footnotes}

${ }^{1}$ For another explanatory framework, including income and several additional factors, but excluding the openness and tradables share variables, see Clague (1985) and (1986).

${ }^{2}$ Tradables are defined here as commodity categories in the final expenditures on GDP, less construction. 
Table 1

Income and Price Leve Is, 1980

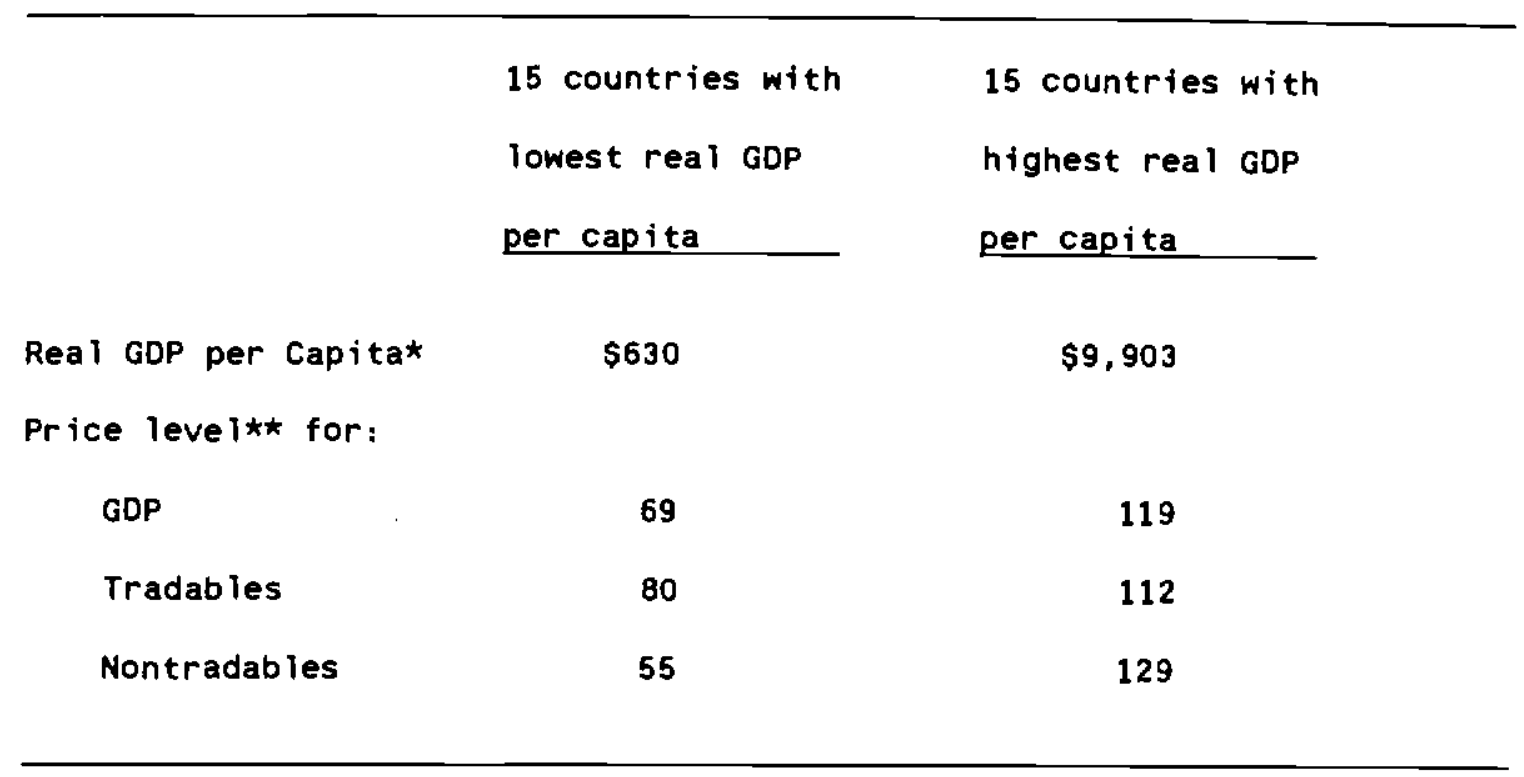

* In 1980 international dollars. For definition of international dollars see Kravis, Heston and Summers, 1982.

** Base is mean of 60 countries weighted by aggregate real GDP.

Source: UN and Commission of the European Communities, 1986 
Table 2

Relation between Trends in Income and Trends in Price Levels

\begin{tabular}{|c|c|c|c|}
\hline & \multicolumn{2}{|c|}{$\begin{array}{l}\text { Coefficients of trend in } y \\
\text { when dependent variable is trend in }\end{array}$} & $\begin{array}{c}\text { Difference } \\
\text { in } \\
\text { Coefficients } \\
(3)=\end{array}$ \\
\hline & PTR & $\begin{array}{l}\text { PNT } \\
\text { (2) }\end{array}$ & $\begin{array}{l}(3)= \\
(1)-(2)\end{array}$ \\
\hline \multicolumn{4}{|l|}{ Al1 } \\
\hline Countries (44) & $\begin{array}{l}-.379 \\
(2.1)\end{array}$ & $\begin{array}{l}-.07 .6 \\
(0.4)\end{array}$ & -.303 \\
\hline Industrial & .085 & .798 & \\
\hline Countries (11) & $(0.2)$ & $(2.8)$ & -.713 \\
\hline Developing & $\therefore$ & & \\
\hline Countries (33) & $\begin{array}{l}-.418 \\
(2.0)\end{array}$ & $\begin{array}{l}-.201 \\
(1.0)\end{array}$ & -.217 \\
\hline
\end{tabular}

Numbers of countries and t-statistics in parentheses 
Appendix Table 1

Equations for Price Levels (PL) as Functions of Real Per Capita GDP(y), openness (OPTI) and the Share of Tradables output in GUP (STI) 3-Year Periods, 1960-1986

\begin{tabular}{|c|c|c|c|c|c|c|c|}
\hline & \multirow{2}{*}{$\begin{array}{c}\text { Constant } \\
\text { Term }\end{array}$} & \multicolumn{4}{|c|}{ Coefficients } & \multirow{2}{*}{$\frac{\bar{R}^{2}}{R M S E}$} & \multirow[b]{2}{*}{$\sigma_{\mathrm{PL}}$} \\
\hline & & y & OPTI & yOPTI & STI & & \\
\hline \multicolumn{8}{|c|}{26 Countries, Based on Phase IV (1980) ICP } \\
\hline $1960-62$ & $\begin{array}{c}124.09 \\
(5.74)\end{array}$ & $\begin{array}{r}.370 \\
(2.92)\end{array}$ & $\begin{array}{l}-0.53 \\
(0.08)\end{array}$ & $\begin{array}{r}-.200 \\
(2.27)\end{array}$ & $\begin{array}{l}-1.61 \\
(4.72)\end{array}$ & $\begin{array}{r}.816 \\
(8.20)\end{array}$ & 58.14 \\
\hline $1963-65$ & $\begin{array}{l}93.86 \\
(3.96)\end{array}$ & $\begin{array}{r}.462 \\
(3.10)\end{array}$ & $\begin{array}{c}3.04 \\
(0.43)\end{array}$ & $\begin{array}{r}-.187 \\
(1.90)\end{array}$ & $\begin{array}{l}-1.08 \\
(2.96)\end{array}$ & $\begin{array}{r}.779 \\
(9.05)\end{array}$ & 59.78 \\
\hline $1966-68$ & $\begin{array}{l}76.83 \\
(3.12)\end{array}$ & $\begin{array}{r}.551 \\
(3.60)\end{array}$ & $\begin{array}{c}5.19 \\
(0.76)\end{array}$ & $\begin{array}{c}-.178 \\
(1.89)\end{array}$ & $\begin{array}{l}-0.87 \\
(2.18)\end{array}$ & $\begin{array}{r}.786 \\
(9.06)\end{array}$ & 59.18 \\
\hline $1969-71$ & $\begin{array}{l}63.60 \\
(2.81)\end{array}$ & $\begin{array}{r}.566 \\
(4.14)\end{array}$ & $\begin{array}{c}4.31 \\
(0.71)\end{array}$ & $\begin{array}{r}-.126 \\
(1.56)\end{array}$ & $\begin{array}{c}0.69 \\
(1.86)\end{array}$ & $\begin{array}{r}.834 \\
(8.24)\end{array}$ & 57.05 \\
\hline $1972-74$ & $\begin{array}{l}34.36 \\
(1.13)\end{array}$ & $\begin{array}{r}.783 \\
(4.15)\end{array}$ & $\begin{array}{c}6.39 \\
(0.90)\end{array}$ & $\begin{array}{r}-.073 \\
(0.77)\end{array}$ & $\begin{array}{c}0.17 \\
(0.35)\end{array}$ & $\begin{array}{r}.841 \\
(10.87)\end{array}$ & 65.22 \\
\hline $1975-77$ & $\begin{array}{l}32.48 \\
(0.90)\end{array}$ & $\begin{array}{r}.780 \\
(3.45)\end{array}$ & $\begin{array}{c}5.83 \\
(0.80)\end{array}$ & $\begin{array}{r}-.018 \\
(0.18)\end{array}$ & $\begin{array}{l}-0.09 \\
(0.15)\end{array}$ & $\begin{array}{r}.817 \\
(13.27)\end{array}$ & 71.82 \\
\hline $1978-80$ & $\begin{array}{l}41.64 \\
(0.96)\end{array}$ & $\begin{array}{l}.792 \\
(2.79)\end{array}$ & $\begin{array}{c}3.20 \\
(0.35)\end{array}$ & $\begin{array}{r}.037 \\
(0.29)\end{array}$ & $\begin{array}{l}-0.17 \\
(0.24)\end{array}$ & $\begin{array}{r}.769 \\
(17.44)\end{array}$ & 79.29 \\
\hline $1981-83$ & $\begin{array}{l}26.05 \\
(0.92)\end{array}$ & $\begin{array}{r}.796 \\
(4.40)\end{array}$ & $\begin{array}{c}6.42 \\
(1.03)\end{array}$ & $\begin{array}{c}-.099 \\
(1.23)\end{array}$ & $\begin{array}{c}0.11 \\
(0.22)\end{array}$ & $\begin{array}{r}.788 \\
(11.62)\end{array}$ & 68.95 \\
\hline $1982-84$ & $\begin{array}{l}29.08 \\
(0.98)\end{array}$ & $\begin{array}{r}.755 \\
(3.88)\end{array}$ & $\begin{array}{c}7.20 \\
(1.03)\end{array}$ & $\begin{array}{r}-.129 \\
(1.43)\end{array}$ & $\begin{array}{c}0.02 \\
(0.05)\end{array}$ & $\begin{array}{r}.718 \\
(12.32)\end{array}$ & 65.30 \\
\hline \multicolumn{8}{|c|}{ Based on Phase $V(1985)$ ICPa } \\
\hline $1982-84^{b}$ & $\begin{array}{l}14.73 \\
(0.34)\end{array}$ & $\begin{array}{r}1.032 \\
(2.67)\end{array}$ & $\begin{array}{l}11.50 \\
(0.87)\end{array}$ & $\begin{array}{r}-.153 \\
(0.86)\end{array}$ & $\begin{array}{l}-0.01 \\
(0.01)\end{array}$ & $\begin{array}{r}.510 \\
(11.66)\end{array}$ & 87.42 \\
\hline $1985-86^{C}$ & $\begin{array}{l}24.48 \\
(0.53)\end{array}$ & $\begin{array}{l}1.006 \\
(2.46)\end{array}$ & $\begin{array}{c}9.99 \\
(0.76)\end{array}$ & $\begin{array}{r}-.148 \\
(.82)\end{array}$ & $\begin{array}{l}-0.10 \\
(0.11)\end{array}$ & $\begin{array}{r}.438 \\
(13.46)\end{array}$ & 89.05 \\
\hline
\end{tabular}


Appendix Table 1 (cont.)

\begin{tabular}{|c|c|c|c|c|c|c|}
\hline & \multirow{2}{*}{$\begin{array}{l}\text { Constant } \\
\text { Term }\end{array}$} & \multicolumn{3}{|c|}{ Coefficients } & \multirow{2}{*}{$\frac{\overrightarrow{\mathrm{R}}^{2}}{\mathrm{RMSE}}$} & \multirow[b]{2}{*}{$\sigma_{\mathrm{PL}}$} \\
\hline & & $\mathrm{y}$ & YOPTI & STI & & \\
\hline \multicolumn{7}{|c|}{26 Countries, Based on Phase IV (1980) ICP } \\
\hline $1960-62$ & $\begin{array}{c}122.63 \\
(9.59)\end{array}$ & $\begin{array}{r}.378 \\
(4.71)\end{array}$ & $\begin{array}{c}-.205 \\
(4.10)\end{array}$ & $\begin{array}{l}-1.59 \\
(6.59)\end{array}$ & $\begin{array}{r}.824 \\
(8.02)\end{array}$ & 58.14 \\
\hline $1963-65$ & $\begin{array}{c}102.19 \\
(7.60)\end{array}$ & $\begin{array}{c}.412 \\
(4.57)\end{array}$ & $\begin{array}{r}-.151 \\
(2.89)\end{array}$ & $\begin{array}{l}-1.20 \\
(4.72)\end{array}$ & $\begin{array}{r}.787 \\
(8.88)\end{array}$ & 59.78 \\
\hline $1966-68$ & $\begin{array}{l}91.43 \\
(6.01)\end{array}$ & $\begin{array}{r}.460 \\
(4.89)\end{array}$ & $\begin{array}{c}-.118 \\
(2.34)\end{array}$ & $\begin{array}{l}-1.07 \\
(3.58)\end{array}$ & $\begin{array}{r}.790 \\
(8.97)\end{array}$ & 59.18 \\
\hline $1969-71$ & $\begin{array}{l}75.20 \\
(5.53)\end{array}$ & $\begin{array}{r}.491 \\
(5.83)\end{array}$ & $\begin{array}{c}-.077 \\
(1.84)\end{array}$ & $\begin{array}{l}-0.86 \\
(3.17)\end{array}$ & $\begin{array}{r}.838 \\
(8.14)\end{array}$ & 57.05 \\
\hline $1972-74$ & $\begin{array}{l}56.60 \\
(3.21)\end{array}$ & $\begin{array}{r}.647 \\
(5.81)\end{array}$ & $\begin{array}{r}-.001 \\
(0.03)\end{array}$ & $\begin{array}{l}-0.47 \\
(1.40)\end{array}$ & $\begin{array}{r}.843 \\
(10.82)\end{array}$ & 65.22 \\
\hline $1975-77$ & $\begin{array}{l}55.30 \\
(2.52)\end{array}$ & $\begin{array}{r}.637 \\
(4.58)\end{array}$ & $\begin{array}{r}.047 \\
(0.82)\end{array}$ & $\begin{array}{l}-0.41 \\
(0.94)\end{array}$ & $\begin{array}{r}.820 \\
(13.17)\end{array}$ & 71.82 \\
\hline $1978-80$ & $\begin{array}{l}53.82 \\
(2.13)\end{array}$ & $\begin{array}{r}.713 \\
(4.20)\end{array}$ & $\begin{array}{r}.074 \\
(1.09)\end{array}$ & $\begin{array}{l}-0.34 \\
(0.66)\end{array}$ & $\begin{array}{r}.778 \\
(17.09)\end{array}$ & 79.29 \\
\hline $1981-83$ & $\begin{array}{l}49.94 \\
(3.09)\end{array}$ & $\begin{array}{r}.644 \\
(6.18)\end{array}$ & $\begin{array}{r}-.024 \\
(0.70)\end{array}$ & $\begin{array}{l}-0.24 \\
(0.69)\end{array}$ & $\begin{array}{r}.787 \\
(11.64)\end{array}$ & 68.95 \\
\hline $1982-84$ & $\begin{array}{l}54.38 \\
(3.30)\end{array}$ & $\begin{array}{r}.590 \\
(5.34)\end{array}$ & $\begin{array}{r}-.045 \\
(1.23)\end{array}$ & $\begin{array}{l}-0.34 \\
(0.95)\end{array}$ & $\begin{array}{r}.718 \\
(12.33)\end{array}$ & 65.30 \\
\hline \multicolumn{7}{|c|}{ Based on Phase $V(1985)$ ICPa $^{a}$} \\
\hline $1982-84^{b}$ & $\begin{array}{l}39.23 \\
(1.18)\end{array}$ & $\begin{array}{r}.741 \\
(3.86)\end{array}$ & $\begin{array}{r}.000 \\
(0.00)\end{array}$ & $\begin{array}{l}-0.08 \\
(0.10)\end{array}$ & $\begin{array}{r}.518 \\
(11.58)\end{array}$ & 87.42 \\
\hline $1985-86^{C}$ & $\begin{array}{l}46.77 \\
(1.34)\end{array}$ & $\begin{array}{r}.738 \\
(3.62)\end{array}$ & $\begin{array}{r}-.013 \\
(0.39)\end{array}$ & $\begin{array}{l}-0.16 \\
(0.20)\end{array}$ & $\begin{array}{r}.454 \\
(13.27)\end{array}$ & 89.05 \\
\hline
\end{tabular}

aOECD data with $O E C D$ weights rather than world weights, as in earlier years.

$c_{21}$ countries 
Appendix Table 2

Equations for Nontradables Price Levels (PLNT) as Functions of

Real Per Capita GDP(y) and Openness (OPTI)

3-Year Periods, 1960-84

\begin{tabular}{|c|c|c|c|c|c|c|}
\hline & \multirow{2}{*}{$\begin{array}{c}\text { Constant } \\
\text { Term }\end{array}$} & \multicolumn{3}{|c|}{ Coefficients } & \multirow{2}{*}{$\frac{\overline{\mathrm{R}}^{2}}{\mathrm{RMSE}}$} & \multirow[b]{2}{*}{${ }^{\sigma} \mathrm{PL}$} \\
\hline & & $y$ & OPT I & YOPTI & & \\
\hline & $\underline{26}$ & Countrie & Based & n Phase & $V(1980)$ & \\
\hline $1960-62$ & $\begin{array}{l}11.14 \\
(1.35)\end{array}$ & $\begin{array}{r}.869 \\
(4.97)\end{array}$ & $\begin{array}{l}19.58 \\
(2.37)\end{array}$ & $\begin{array}{r}-.355 \\
(2.36)\end{array}$ & $\begin{array}{r}.580 \\
(15.12)\end{array}$ & 23.32 \\
\hline $1963-65$ & $\begin{array}{l}10.24 \\
(1.79)\end{array}$ & $\begin{array}{r}.911 \\
(7.75)\end{array}$ & $\begin{array}{l}17.77 \\
(3.17)\end{array}$ & $\begin{array}{l}-.340 \\
(3.44)\end{array}$ & $\begin{array}{r}.782 \\
(10.18)\end{array}$ & 21.79 \\
\hline $1966-68$ & $\begin{array}{l}10.89 \\
(2.12)\end{array}$ & $\begin{array}{r}.912 \\
(9.02)\end{array}$ & $\begin{array}{l}14.11 \\
(2.93)\end{array}$ & $\begin{array}{r}-.277 \\
(3.42)\end{array}$ & $\begin{array}{r}.847 \\
(8.45)\end{array}$ & 21.58 \\
\hline $1969-71$ & $\begin{array}{c}9.35 \\
(1.88)\end{array}$ & $\begin{array}{r}.873 \\
(8.91)\end{array}$ & $\begin{array}{l}10.91 \\
(2.39)\end{array}$ & $\begin{array}{l}-.219 \\
(2.94)\end{array}$ & $\begin{array}{r}.861 \\
(8.31)\end{array}$ & 22.31 \\
\hline $1972-74$ & $\begin{array}{l}8.60 \\
(1.72)\end{array}$ & $\begin{array}{r}.961 \\
(9.49)\end{array}$ & $\begin{array}{c}7.96 \\
(2.01)\end{array}$ & $\begin{array}{c}-.133 \\
(1.98)\end{array}$ & $\begin{array}{r}.909 \\
(8.54)\end{array}$ & 28.26 \\
\hline $1975-77$ & $\begin{array}{l}11.23 \\
(1.82)\end{array}$ & $\begin{array}{r}.955 \\
(7.62)\end{array}$ & $\begin{array}{c}6.05 \\
(1.43)\end{array}$ & $\begin{array}{r}-.070 \\
(0.97)\end{array}$ & $\begin{array}{r}.893 \\
(10.44)\end{array}$ & 31.88 \\
\hline $1978-80$ & $\begin{array}{l}14.02 \\
(1.55)\end{array}$ & $\begin{array}{r}.994 \\
(5.54)\end{array}$ & $\begin{array}{c}5.31 \\
(0.92)\end{array}$ & $\begin{array}{l}-.030 \\
(0.30)\end{array}$ & $\begin{array}{r}.838 \\
(14.85)\end{array}$ & 36.85 \\
\hline $1981-83$ & $\begin{array}{l}15.68 \\
(2.69)\end{array}$ & $\begin{array}{r}.894 \\
(8.36)\end{array}$ & $\begin{array}{c}5.87 \\
(1.56)\end{array}$ & $\begin{array}{r}-.114 \\
(1.98)\end{array}$ & $\begin{array}{r}.873 \\
(9.73)\end{array}$ & 27.33 \\
\hline $1982-84$ & $\begin{array}{l}14.07 \\
(2.26)\end{array}$ & $\begin{array}{r}.882 \\
(7.81)\end{array}$ & $\begin{array}{c}7.26 \\
(1.74)\end{array}$ & $\begin{array}{l}-.149 \\
(2.40)\end{array}$ & $\begin{array}{r}.836 \\
(10.31)\end{array}$ & 25.48 \\
\hline
\end{tabular}


Appendix Table 3

Equations for Tradables Price Levels (PLTR) as Functions of

Real Per Capita GDP(y) and Openness (OPTI)

3-Year Periods, 1960-\$984

\begin{tabular}{|c|c|c|c|c|c|c|}
\hline & \multirow{2}{*}{$\begin{array}{c}\text { Constant } \\
\text { Term }\end{array}$} & \multicolumn{3}{|c|}{ Coefficients } & \multirow{2}{*}{$\frac{\bar{R}^{2}}{\text { RMSE }}$} & \multirow[b]{2}{*}{$\sigma_{P L}$} \\
\hline & & $y$ & OPTI & YOPTI & & \\
\hline & \multicolumn{2}{|c|}{26 Countries, } & Based on & Phase IV & $(1980)$ IC & \\
\hline $1960-62$ & $\begin{array}{l}35.07 \\
(3.52)\end{array}$ & $\begin{array}{r}.736 \\
(3.50)\end{array}$ & $\begin{array}{l}19.19 \\
(2.01)\end{array}$ & $\begin{array}{l}-.365 \\
(2.02)\end{array}$ & $\begin{array}{r}.350 \\
(18.23)\end{array}$ & 22.61 \\
\hline $1963-65$ & $\begin{array}{l}39.50 \\
(3.38)\end{array}$ & $\begin{array}{r}.696 \\
(2.90)\end{array}$ & $\begin{array}{l}19.03 \\
(1.67)\end{array}$ & $\begin{array}{r}-.304 \\
(1.51)\end{array}$ & $\begin{array}{r}.288 \\
(20.75)\end{array}$ & 24.59 \\
\hline $1966-68$ & $\begin{array}{l}36.86 \\
(3.14)\end{array}$ & $\begin{array}{l}.713 \\
(3.08)\end{array}$ & $\begin{array}{l}18.33 \\
(1.66)\end{array}$ & $\begin{array}{r}-.274 \\
(1.47)\end{array}$ & $\begin{array}{r}.346 \\
(19.35)\end{array}$ & 23.93 \\
\hline $1369-71$ & $\begin{array}{l}36.00 \\
(3.72)\end{array}$ & $\begin{array}{r}.645 \\
(3.38)\end{array}$ & $\begin{array}{l}15.79 \\
(1.78)\end{array}$ & $\begin{array}{r}-.183 \\
(1.26)\end{array}$ & $\begin{array}{r}.500 \\
(16.19)\end{array}$ & 22.88 \\
\hline $1972-74$ & $\begin{array}{l}41.74 \\
(3.60)\end{array}$ & $\begin{array}{r}.730 \\
(3.12)\end{array}$ & $\begin{array}{l}10.57 \\
(1.16)\end{array}$ & $\begin{array}{l}-.064 \\
(0.42)\end{array}$ & $\begin{array}{r}.586 \\
(19.75)\end{array}$ & 30.71 \\
\hline $1975-77$ & $\begin{array}{l}43.82 \\
(3.63)\end{array}$ & $\begin{array}{r}.682 \\
(2.78)\end{array}$ & $\begin{array}{l}10.40 \\
(1.26)\end{array}$ & $\begin{array}{c}-.018 \\
(0.12)\end{array}$ & $\begin{array}{r}.616 \\
(20.42)\end{array}$ & 32.95 \\
\hline $1978-80$ & $\begin{array}{l}50.76 \\
(3.84)\end{array}$ & $\begin{array}{r}.684 \\
(2.60)\end{array}$ & $\begin{array}{c}5.34 \\
(0.63)\end{array}$ & $\begin{array}{r}.062 \\
(0.43)\end{array}$ & $\begin{array}{r}.650 \\
(21.75)\end{array}$ & 36.77 \\
\hline $1981-83$ & $\begin{array}{l}49.46 \\
(4.91)\end{array}$ & $\begin{array}{r}.647 \\
(3.50)\end{array}$ & $\begin{array}{c}6.34 \\
(0.98)\end{array}$ & $\begin{array}{c}-.083 \\
(0.83)\end{array}$ & $\begin{array}{r}.551 \\
(15.79)\end{array}$ & 25.06 \\
\hline $1982-84$ & $\begin{array}{l}49.94 \\
(4.45)\end{array}$ & $\begin{array}{r}.593 \\
(2.91)\end{array}$ & $\begin{array}{c}7.37 \\
(0.98)\end{array}$ & $\begin{array}{r}-.107 \\
(0.96)\end{array}$ & $\begin{array}{r}.398 \\
(18.57)\end{array}$ & 23.94 \\
\hline
\end{tabular}


Appendix Table 4

Correlations Among Price Levels

and Among Residuals from Structural Equations

26 Countries, 1972-1984

\begin{tabular}{|c|c|c|c|c|c|}
\hline & $1972-74$ & $1975-77$ & $1978-80$ & $1981-83$ & $1982-84$ \\
\hline \multicolumn{6}{|c|}{ Correlations Among Price Levels } \\
\hline $1972-74$ & 1.000 & .984 & .950 & .915 & .883 \\
\hline $1975-77$ & & 1.000 & .975 & .929 & .892 \\
\hline $1978-80$ & & & 1.000 & .926 & .876 \\
\hline $1981-83$ & & & & 1.000 & .985 \\
\hline $1982-84$ & & & & & 1.000 \\
\hline \multicolumn{6}{|c|}{ Correlations Among Residuals from Structural Equations } \\
\hline $1972-74$ & 1.000 & .899 & .742 & .359 & .255 \\
\hline $1975-77$ & & 1.000 & .886 & .406 & .241 \\
\hline $1978-80$ & & & 1.000 & .413 & .163 \\
\hline $1981-83$ & & & & 1.000 & .934 \\
\hline $1982-84$ & & & & & 1.000 \\
\hline
\end{tabular}


Appendix Table 5

Correlations Among Tradables Price Levels and Among Residuals from Structural Equations of Different Periods 26 Countries, 1972-1984

\begin{tabular}{|c|c|c|c|c|c|}
\hline & $1972-74$ & $1975-77$ & $1978-80$ & $1981-83$ & $1982-84$ \\
\hline \multicolumn{6}{|c|}{ Correlations Among Price Levels } \\
\hline $1972-74$ & 1.000 & .964 & .938 & .746 & .664 \\
\hline $1975-77$ & & 1.000 & .972 & .825 & .748 \\
\hline $1978-80$ & & & 1.000 & .860 & .770 \\
\hline $1981-83$ & & & & 1.000 & .969 \\
\hline \multirow[t]{2}{*}{$1982-84$} & & & & & 1.000 \\
\hline & Correlations & Among Res $i$ & als from & Structural & Equations \\
\hline $1972-74$ & 1.000 & .913 & .832 & .227 & .135 \\
\hline $1975-77$ & & 1.000 & .917 & .389 & .274 \\
\hline $1978-80$ & & & 1.000 & .429 & .259 \\
\hline $1981-83$ & & & & 1.000 & .951 \\
\hline $1982-84$ & & & & & 1.000 \\
\hline
\end{tabular}


Appendix Table 6

Correlations Among Nontradables Price Levels

and Among Residuals from Structural Equations of Different Periods

26 Countries, 1972-1984

\begin{tabular}{|c|c|c|c|c|c|}
\hline & $1972-74$ & $1975-77$ & $1978-80$ & $1981-83$ & $1982-84$ \\
\hline \multicolumn{6}{|c|}{ Correlations Among Price Levels } \\
\hline $1972-74$ & 1.000 & .988 & .949 & .956 & .943 \\
\hline $1975-77$. & & 1.000 & .975 & .956 & .935 \\
\hline $1978-80$ & & & 1.000 & .948 & .915 \\
\hline $1981-83$ & & & & 1.000 & .992 \\
\hline $1982-84$ & & & & & 1.000 \\
\hline \multicolumn{6}{|c|}{ Correlations Among Residuals from Structural Equations } \\
\hline $1972-74$ & 1.000 & .870 & .600 & .498 & .433 \\
\hline $1975-77$ & & 1.000 & .844 & .413 & .264 \\
\hline $1978-80$ & & & 1.000 & .414 & .167 \\
\hline $1981-83$ & & & & 1.000 & .944 \\
\hline $1982-84$ & & & & & 1.000 \\
\hline
\end{tabular}


Appendix Table 7

Equations Relating Change in Tradables/Nontradables Price Ratio to Change in Exchange Rate

( 26 countries)

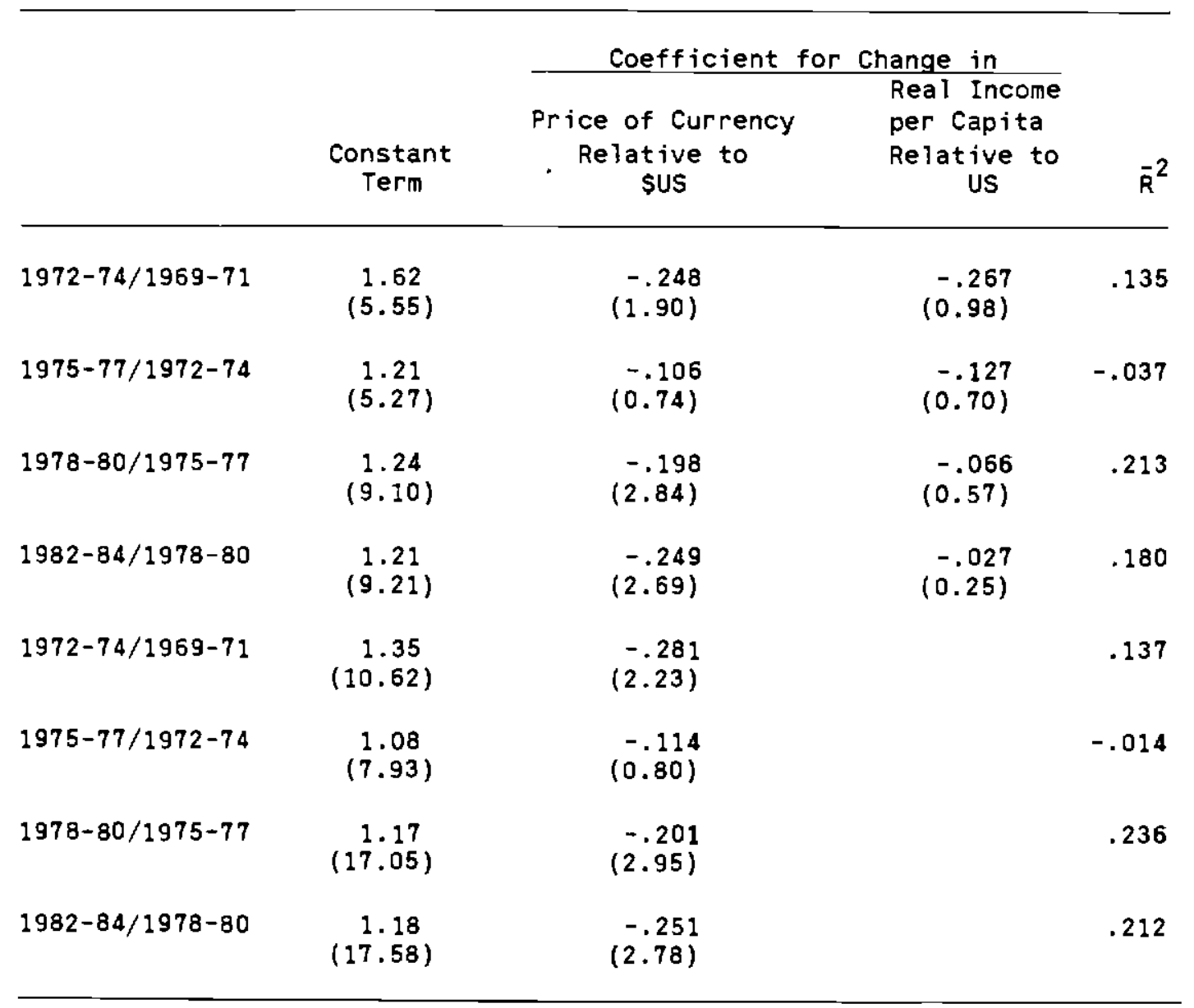


Equations Relating Changes in Price Levels $(P L)$ to Changes in Per Capita Income ( $Y$ ), Openness (OPTI), Share of Tradables in Jutput (STI). and Residual from Initial Structural Price Level Equation (RES) (26 countries)

Constant
Term Y OPTI STI YOPTI RES $\bar{R}^{2}$

Equations in Relative Changes

$\begin{array}{lccccccc}82-84 / 60-62 & -3.05 & 1.47 & 1.42 & 1.75 & -.645 & -.0582 & .312 \\ 69-71 / 60-62 & (1.81) & (2.02) & (2.38) & (1.86) & (2.08) & (3.37) & \\ & -2.44 & 2.79 & 2.93 & 0.01 & -2.33 & -.0208 & .165 \\ 82-84 / 69-71 & (1.00) & (1.51) & (1.67) & (0.01) & (1.53) & (2.18) & \\ & & & & & & & \\ & 4.13 & -2.61 & -2.20 & 0.32 & 1.73 & -.0027 & .414\end{array}$

Equations in Arithmetic Changes

$82-84$ minus $60-62$

$\begin{array}{llllll}2.46 & 0.866 & -1.45 & 0.13 & -0.02 & -1.22\end{array}$ .293

$69-71$ minus $60-62$

$\begin{array}{llllll}-7.69 & 0.638 & 6.88 & -1.15 & 0.27 & -0.45\end{array}$ $(3.74)(1.87)(1.01)(2.39)(0.18) \quad(2.15)$

82-84 minus $69-71$

$\begin{array}{llllll}13.87 & 0.316 & -18.85 & 0.66 & 1.55 & -0.56\end{array}$ .256 $\begin{array}{lllll}(3.59) & (0.98) & (2.19) & (1.07) & (1.97) \quad(1.74)\end{array}$ 